\title{
Use of Communication Strategies by Tourism-Oriented EFL Learners in Relation to Gender and Perceived Language Ability
}

\author{
Tao Zhao ${ }^{1}$ \& Channarong Intaraprasert ${ }^{1}$ \\ ${ }^{1}$ School of Foreign Languages, Institute of Social Technology, Suranaree University of Technology, Thailand \\ Correspondence: Tao Zhao, Surasammanakhan Hotel, Suranaree University of Technology, 111 University \\ Avenue, Muang District, Nakhon Ratchasima 30000, Thailand. Tel: 86-139-8511-2077. E-mail: \\ tzhao65@hotmail.com
}

Received: April 7, 2013 Accepted: April 26, 2013 Online Published: June 3, 2013

doi:10.5539/elt.v6n7p46 URL: http://dx.doi.org/10.5539/elt.v6n7p46

\begin{abstract}
This study was intended to explore the relationship of gender, perceived language ability with communication strategy use by tourism-oriented EFL learners studying at the universities in the Southwest China to improve and maintain their oral communication in English. The Communication Strategy Questionnaire was used for data collection, and the quantitative method such as Analysis of Variance (ANOVA) and Chi-square tests were employed for data analysis. The results demonstrated that although the gender and perceived language ability had minor relationship with students' overall use of communication strategy, the gender and the perceived language ability showed their significant variations in the students' choice of individual communication strategies.
\end{abstract}

Keywords: communication strategies, tourism-oriented EFL learners, gender, perceived language ability

\section{Introduction}

In the modern society, people are highly aware of the importance of English since they need it for communication in the 'global village'. English is for communication and it truly links the world together. Crystal (2003) described that the rise of English as a global language plays an irreplaceable role in the modern society. In China, English has nowadays been increasingly learned and used as a foreign language with its rapid development of economy, which also facilitates the development of the tourism industry because Chinese governments are encouraging their citizens to learn English, parents are persuading, even forcing, their children to speak it and college students are doing English at the expense of their majors (Jiang, 2003).

According to China Daily (2004), the World Tourism Organization (WTO) predicted that China would be the world's largest tourist destination by the year 2020 and English would play a more important role in the development of the world's tourism industry. Feng (2011) claimed that with the rapid development of tourism industry, China now needs millions of English-speaking people to work in a variety of tourism fields, including hotels, travel agencies and tour guides, etc. Accordingly, the tourism-oriented EFL teaching should be reformed to meet the needs of the developing society.

The tourism-oriented EFL learners in China can usually be enrolled in the schools of different levels: colleges or universities, vocational colleges, and secondary vocational schools. The tourism-oriented EFL learners in colleges or universities are expected to have better English language proficiency, especially their oral communication competence for the future career. However, compared with the EFL learners in the developed areas of China, the EFL learners in underdeveloped or developing areas find it difficult to orally communicate due to lack of communicative opportunities and communication strategies while communicating with people (Zhang, 2007), and the tourism-oriented EFL learners in this area are facing the same problems in the English communication. Researches have been increasingly conducted to improve the tourism-oriented EFL learners' communication ability.

\subsection{Communication Strategies}

The research results of communication strategy used by EFL learners have contributed to EFL learners' communication in English in the past years. Tarone et al. (1976, p. 5) provided an early definition of communication strategies (CSs) as "a systematic attempt by the learner to express or decode meaning in the 
target language, in situations where the appropriate systematic target language rules have not been formed". Furthermore, Tarone (1983, p. 419) defined communication strategies as "mutual attempt[s] of two interlocutors to agree on a meaning in situations where requisite meaning structures do not seem to be shared". As these strategies reflect learners' attempts to make themselves understood to their interlocutors, they are considered interactional in nature. Moreover, Tarone (1983, p. 65) offered the following necessary criteria for communication strategies, in which she explicitly distinguished production strategies from learning strategies: 1) A speaker desires to communicate meaning to a listener; 2) The speaker believes the linguistic or sociolinguistic structure desired to communicate meaning and the structure is unavailable or is not shared with the listener; 3 ) The speaker chooses to: a) avoid - not attempt to communicate meaning; or b) attempt alternate means to communicate meaning. The speaker stops trying alternatives when it seems clear to the speaker that there is shared meaning. It was accepted that communication strategies are alternate means to express a concept or an intention, the correct way of saying which does not exist in learners' interlanguage system. The three criteria are needed to be fulfilled for a strategy to be called communication strategy.

Terrel (1977, p. 334) asserted that "communication strategies are crucial at the beginning stages of second language learning". Similarly, Bialystok (1990, p. 116) viewed that "communication strategies are an undeniable event of language use, their existence is a reliable documented aspect of communication and their role in second language communication seems particularly salient". Furthermore, Larsen-Freeman and Long (1991) pointed out that all communication strategies are helpful for language acquisition because they enable learners to keep the conversation going and thereby provide more opportunities for input. Similarly, O’Malley and Chamot (1990, p. 43) insisted that communication strategies are particularly important "in negotiating meaning where either linguistic structures or sociolinguistic rules are not shared between a second-language learner and a speaker of the target language". They also stated that communication strategies are used to promote communication. That is, communication strategies are employed not only to repair oral communication problems but also to improve the effectiveness of communication.

Dörnyei (1995) brought up an important and interesting point in his study on the teachability of CSs and even further suggested that "some people can communicate effectively in an L2 with only 100 words. The importance of CSs has been recognized and attracted many researchers' interests. A great number of research works on communication strategies have been conducted. The first group has mainly focused on the nature of communication strategies, namely, the definitions, identifications and classifications (e.g. Bui and Intaraprasert, 2012; Bialystok, 1983 and 1990; Mariani, 2010; Nakatani, 2006; Somsai and Intaraprasert, 2011; Tarone, 1977). Secondly, there are empirical studies which have investigated the use of communication strategies in relation to different factors, such as communicative tasks, learners' general language proficiency and types of programs (e.g. Liskin-Gasparro, 1996; Paramasivam, 2009; Wannaruk, 2003).

However, although the role of communication strategies in developing learners' communication competence is important, very few studies have been conducted with Chinese students. To the best knowledge of the researcher, no research has ever investigated on communication strategy use by tourism-oriented EFL learners in relation to the gender and perceived language ability in China. Thus, this present investigation aimed to fill this gap. The two variables of student's gender and perceived language ability are hypothesized to have impact on use of communication strategies among tourism-oriented EFL learners in China.

\subsection{Research Objectives and Questions}

The present study was conducted with exploratory purposes. It aimed at:

- Investigating whether the choices of communication strategy use vary significantly by the students' gender and perceived language ability

- Examining the patterns of a significant variation in the frequency of the students' reported communication strategy use at different aspects of the overall, categorized and individual CSs use with reference to the gender and perceived language ability

The research questions for the present study were: 1) What is the overall frequency of each type of communication strategies employed by Chinese tourism-oriented EFL learners in relation to gender and perceived language ability? 2) Does the employment of strategies for coping with oral communication problems vary significantly according to the gender of students and their perceived language ability? If it does, what are they?

\section{Research Methodology}

The five aspects related to the research methodology in the following were presented to make the research clear 
for the present study.

\subsection{Terms Used in the Study \\ Communication Strategies}

The term 'communication strategies' for the present investigation refers to knowledge or ability used by tourism-oriented EFL learners to cope with oral communication problems due to their inadequate linguistic knowledge and sociocultural knowledge in an oral communication in English as well as learning techniques employed by the students in an oral interaction in order to improve, and maintain their oral communication in English. Communication strategies may occur in either pseudo communication or real-life communication both inside and outside language classroom settings. In the present study, 'communication strategies' and 'strategies for coping with oral communication problems' will be used interchangeably.

\section{Students}

'Students' for the present study refers to Chinese undergraduate students who are tourism-oriented EFL learners from Guizhou University and Guizhou Normal College in Guizhou Province, Yunnan University and Yunnan Normal University in Yunnan Province and Guangxi University and Guangxi University for Nationalities in Guangxi Province which are in the southwest of China (a part of developing areas in China).

\section{Perceived Language Ability}

In the present investigation, 'Perceived Language Ability' refers to students' language proficiency level based on their own evaluation in the questionnaire. The perceived language ability is self-evaluated as poor (under 60 score), fair (60-79 score) or good (over 80) based on 100 (full score) of their overall English language ability.

\subsection{Participants}

Because not all the universities in the Southwest China offer tourism-oriented bachelor degree program, convenience sampling method was adopted for data collection. 814 tourism-oriented EFL learners were purposively selected from 6 universities ( 2 universities in Yunnan Province, 2 universities in Guizhou Province and 2 in Guangxi Province). The detailed information about the 814 participants is in Table 2.

\subsection{Instruments}

The communication strategy questionnaire (CSQ) in the appendix was employed in this study which was modified by the researcher based on the typologies of communication strategies by Dörnyei and Scott (1997), Mariani (2010), Nakatani, (2006), and Somsai and Inatarprasert (2011), which are considered as the most recently established ones. With aiming at the research objectives, the research context, and the operational definition of communication strategies of this present study, this questionnaire was made up of 35 items, including 20 items of strategies for coping with communication problems (CCP), 10 items of strategies for understanding interlocutor's messages (UIM), and 5 items of strategies for carrying on the conversation as intended (CCI). These items were firstly translated from English into Chinese by the researcher in order to avoid the respondents' misunderstanding or unanswering, and then were double checked by two Chinese experts in the field of Teaching English as a Foreign Language (TEFL). The questionnaire was piloted to prove that the reliability estimate of Alpha Coefficient ( $\alpha$ ) or Cronbach Alpha for the overall communication strategies was .84, which was higher when compared with the acceptable reliability of .70 for research purposes (Fraenkel \& Wallen, 1993). A few items of CSs were revised again based on the research objectives. The Chinese translation has been improved for better understanding according to piloting participants' suggestions.

\subsection{Procedure}

During November and December, 2012, the researcher went to six universities in the Southwest China in person to collect the data responded to the CSQ, to which 814 university tourism-oriented EFL learners gave their responses.

\subsection{Analysis}

The quantitative method was employed to analyze the data collected in the present study. The SPSS software was used to analyze the data obtained from the questionnaire to examine the relationship between the participants' communication strategies use and the variables.

- Analysis of Variance (ANOVA)

Analysis of variance (ANOVA) was used to compare and test the significant difference among the means of two or more groups on a dependent variable. This statistics would be used to examine the relationship between the overall use of learner-reported communication strategy and each of the selected independent variables, i.e., 
gender of students and perceived language ability.

- The Post-hoc Scheffe Test

The post hoc Scheffe test was used to determine the variation at levels of perceived language ability of poor, fair and good students.

- The Chi-square Test

The chi-square test was used to determine use of strategies at the individual item aspect.

Furthermore, the reliability of the CSQ was examined to see whether the data would be reliable before the present study. The results of Alpha Coefficient $(\alpha)$ or Cronbach Alpha was used to check the internal consistency of the CSQ. The reliability of the overall communication questionnaire was 0.90 which was much higher than the average of the other three categories and considered acceptable. The reliability estimate was above the acceptable criterion of 0.70 as suggested in Fraenkel and Wallen (1993). The reliability estimate of the CSQ and its categories according to 814 Chinese tourism-oriented EFL learners has been demonstrated in Table 1 below.

Table 1. Reliability estimate of the CSQ as a whole and the three categories

\begin{tabular}{lcccc}
\hline Communication Strategy & CSQ as a Whole & CCP Category & UIM Category & CCI Category \\
Questionnaire (CSQ) & $(35$ items $)$ & $(20$ items $)$ & $(10$ items $)$ & $(5$ items $)$ \\
Reliability Estimate & .90 & .84 & .83 & .72 \\
(Alpha Coefficient: $\alpha)$ & & & & \\
\hline
\end{tabular}

\section{Findings}

The following analysis was the findings of variation in frequency of different aspects of communication strategy use, in which overall reported CS use, use of strategies in the CCP, UIM and CCI categories and use of individual communication strategies were presented.

\subsection{Variation in Frequency of the Students' Overall Reported CS Use}

Table 2. A summary of overall reported CS use

\begin{tabular}{lcccccc}
\hline Variables & & Number & Mean & S.D & Sig. Level & Variation Pattern \\
Gender & Male & 261 & 2.57 & .38 & N.S & -- \\
& Female & 553 & 2.56 & .37 & & N.S. \\
\hline Perceived & Good & 127 & 2.56 & .42 & & \\
Language & Fair & 496 & 2.58 & .36 & & \\
Ability & Poor & 191 & 2.56 & .38 & & \\
\hline
\end{tabular}

Note: 'N.S.' stands for no significance.

As shown in Table 2, the results from ANOVA revealed that the frequency of students' overall strategy use did not vary significantly according to students' gender and perceived language ability.

3.2 Variation in Frequency of the Students' Use of CS under Three Categories

3.2.1 Variation according to the Students' Gender

Table 3. Variation in frequency of students' use of CSs in the CCP, UIM, CCI categories according to students' gender

\begin{tabular}{|c|c|c|c|c|c|c|}
\hline \multirow[t]{2}{*}{ Strategy Category } & \multicolumn{2}{|c|}{ Male $(n=261)$} & \multicolumn{2}{|c|}{ Female $(\mathrm{n}=553)$} & \multirow[t]{2}{*}{ Sig. Level } & \multirow[t]{2}{*}{ Variation Pattern } \\
\hline & Mean & S.D & Mean & S.D & & \\
\hline CCP Category & 2.54 & .42 & 2.52 & .41 & N.S & $\begin{array}{ll}-- \\
--\end{array}$ \\
\hline UIM Category & 2.66 & .50 & 2.69 & .49 & N.S & --- \\
\hline CCI Category & 2.56 & .51 & 2.50 & .55 & N.S & --- \\
\hline
\end{tabular}

As shown in Table 3, the results from the ANOVA showed that no significant difference was found in the frequency of the use of communication strategies in the CCP, UIM, CCI categories according to the gender of students. 
Table 4. Variation in frequency of students' use of CSs in the CCP, UIM, CCI categories according to the students' perceived language ability

\begin{tabular}{lcrrrrrrc}
\hline Strategy Category & \multicolumn{2}{c}{ Good $(\mathrm{n}=127)$} & \multicolumn{2}{c}{ Fair $(\mathrm{n}=496)$} & \multicolumn{2}{c}{ Poor $(\mathrm{n}=191)$} & Sig. Level & Variation Pattern \\
& Mean & S.D & Mean & S.D & Mean & S.D & & \\
\hline CCP Category & 2.53 & .47 & 2.54 & .39 & 2.50 & .42 & N.S & --- \\
UIM Category & 2.59 & .52 & 2.68 & .47 & 2.70 & .54 & $\mathrm{P}<.05$ & Poor $>$ Fair $>$ Good \\
CCI Category & 2.64 & .55 & 2.51 & .54 & 2.45 & .54 & $\mathrm{P}<.05$ & Good $>$ Fair $>$ Poor \\
\hline
\end{tabular}

The results from ANOVA in Table 4 demonstrated that significant difference was found in the use of strategies related to perceived language ability in the UIM and CCI categories, although no significant difference was found in the CCP category. In the UIM category, the students who were poor in perceived language ability employed the strategies significantly more frequently than those who are good and fair at perceived language ability. It meant that the students who were poor in perceived language ability needed more help in understanding the interlocutor's messages. In the CCI category, the students who were good at perceived language ability employed the strategies significantly more frequently than the fair ones and the poor ones and those students who were fair at perceived language ability employed the strategies significantly more frequently than the poor ones.

\subsection{Variation in Frequency of the Students' CS Use at Individual Aspect}

This section was intended to present the results of Chi-square tests which were employed to determine the patterns of the significant variations in students' reported strategy use at the individual strategy aspect. The Chi-square tests were used to check all the individual strategy items for the significant variations by the two independent variables. To demonstrate the significant variation, the percentage of students in terms of each variable reported the high strategy use ( 3 and 4 in the strategy questionnaire), and the observed Chi-square value $\left(\chi^{2}\right)$ which showed the strength of variation in use of each individual strategy were identified. The individual strategies were presented in order of the percentage of students reporting the high use ( 3 and 4 in the strategy questionnaire), ranking from the highest to the lowest. This made it easier to see an overall picture of the communication strategies which were reported to be frequently used, analyzed in terms of each of the two variables. The pattern(s) of the significant variations of the particular strategy items were included in a brief discussion of each variable.

\subsubsection{Variation according to the Students' Gender}

Table 5. Variation in frequency of students' use of individual CSs according to students' gender

\begin{tabular}{|c|c|c|c|}
\hline Individual Communication Strategies & \multicolumn{2}{|c|}{$\%$ of high use ( 3 and 4$)$} & \multirow{2}{*}{$\begin{array}{c}\text { Observed } \chi^{2} \\
\mathrm{P}<.05\end{array}$} \\
\hline Used more by female students- 4 strategies & Male & Female & \\
\hline CCP 5 Using simple expressions & 69.3 & 78.5 & $\chi^{2}=9.06$ \\
\hline CCP 2 Using familiar words, phrases or sentences & 65.1 & 77.6 & $\chi^{2}=19.1$ \\
\hline UIM 6 Trying to catch the interlocutor's main point & 65.9 & 74.5 & $\chi^{2}=8.8$ \\
\hline $\begin{array}{l}\text { UIM10 Noticing the interlocutor's gestures } \\
\text { and facial expressions }\end{array}$ & 62.8 & 68.4 & $\begin{array}{c}\chi^{2}=13.89 \\
\mathrm{P}<.01\end{array}$ \\
\hline $\begin{array}{l}\text { CCP } 15 \text { Appealing help from the interlocutor } \\
\text { either verbally or non-verbally }\end{array}$ & 49.4 & 42.9 & $\begin{aligned} & \chi^{2}=10.13 \\
& \mathrm{P}<.05\end{aligned}$ \\
\hline $\begin{array}{l}\text { CCI } 3 \text { Feeling all right for taking risks } \\
\text { while speaking }\end{array}$ & 41.8 & 29.1 & $\begin{array}{l}\chi^{2}=14.67 \\
\mathrm{P}<.001\end{array}$ \\
\hline CCP 9 Repeating what the interlocutor has just said & 37.2 & 33.3 & $\begin{aligned} \chi^{2} & =10.24 \\
\mathrm{P} & <.05\end{aligned}$ \\
\hline $\begin{array}{l}\text { CCP } 20 \text { Making up a new word in order to } \\
\text { communicate a desired concept }\end{array}$ & 33.3 & 20.6 & $\begin{array}{c}\chi^{2}=24.2 \\
\mathrm{P}<.001\end{array}$ \\
\hline CCP 17 Drawing a picture & 26.8 & 15.2 & $\begin{array}{c}\chi^{2}=18.67 \\
\mathrm{P}<.001\end{array}$ \\
\hline
\end{tabular}


The results from the Chi-square tests in Table 5 revealed that six individual CCP strategies, two individual UIM strategies, and one individual CCI strategy varied significantly according to the gender.

In addition, the results from the Chi-square tests in Table 5 showed that the female students reported significantly higher use of 4 strategies than their male counterparts did, for example, 'Using simple expressions CCP 5 ' (78.5\% females and $69.3 \%$ males) and 'Noticing the interlocutor's gestures and facial expressions UIM 10' ( $68.4 \%$ females and $62.8 \%$ males).

However, the results from the Chi-square tests in Table 5 also revealed that the male students reported significantly higher use of other 5 strategies than their female counterparts did, for example, 'Making up a new word in order to communicate a desired concept CCP 20' (33.3\% males and females 20.6\%). Furthermore, 'Feeling all right for taking risks while speaking CCI 3' (41.8 \% males and $29.1 \%$ females) demonstrated that male tourism-oriented EFL learners were more likely to be confident and risk-takers in employing communication strategies.

3.3.2 Variation according to the Students' Perceived Language Ability

Table 6. Variation in frequency of students' use of individual CSs according to perceived language ability

\begin{tabular}{|c|c|c|c|c|}
\hline Individual Communication Strategies & \multicolumn{3}{|c|}{$\%$ of high use ( 3 and 4$)$} & Observed $\chi^{2}$ \\
\hline $\begin{array}{l}\text { Used More by Good, Fair and Poor Students } \\
\text { of Perceived Language Ability - } 9 \text { strategies }\end{array}$ & Good & Fair & Poor & $\mathrm{P}<.05$ \\
\hline CCP 2 Using familiar words, phrases or sentences & 81.2 & 75.8 & 62.8 & $\begin{array}{r}\chi^{2}=18.14 \\
\mathrm{P}<.001\end{array}$ \\
\hline $\begin{array}{l}\text { CCP } 11 \text { Correcting the incorrect and inappropriate } \\
\text { utterances by yourself }\end{array}$ & 57.5 & 53.4 & 40.8 & $\begin{aligned} \chi^{2}=23.36 \\
\mathrm{P}<.001\end{aligned}$ \\
\hline CCP 1 Using synonym or antonym & 56.7 & 47.6 & 36.6 & $\begin{array}{r}\chi^{2}=18.68 \\
\mathrm{P}<.05\end{array}$ \\
\hline $\begin{array}{l}\text { CCP } 3 \text { Correcting one's own pronunciation, } \\
\text { grammar and lexical mistakes }\end{array}$ & 52.8 & 49.4 & 37.7 & $\begin{array}{r}\chi^{2}=23.70 \\
P<.05\end{array}$ \\
\hline CCI 1 Trying to enjoy the conversation & 51.2 & 51.6 & 39.8 & $\begin{array}{r}\chi^{2}=15.30 \\
P<.05\end{array}$ \\
\hline CCP 12 Thinking in Chinese before speaking & 48.8 & 66.1 & 62.3 & $\begin{array}{l}\chi^{2}=16.4 \\
P<.05\end{array}$ \\
\hline $\begin{array}{l}\text { UIM } 9 \text { Trying to translate into Chinese little by little } \\
\text { to understand what the interlocutor has said }\end{array}$ & 44.9 & 62.9 & 58.6 & $\begin{aligned} \chi^{2}=17.0 \\
P<.05\end{aligned}$ \\
\hline $\begin{array}{l}\text { CCI } 5 \text { Responding to the interlocutor despite } \\
\text { an imperfect understanding of the message }\end{array}$ & 34.6 & 47.6 & 45.0 & $\begin{aligned} \chi^{2}= & 15.8 \\
& P<.05\end{aligned}$ \\
\hline UIM 3 Asking the interlocutor to simplify the language & e 32.3 & 49.8 & 53.9 & $\begin{aligned} \chi^{2}= & 27.67 \\
& \mathrm{P}<.001\end{aligned}$ \\
\hline
\end{tabular}

The results from the Chi-square tests in Table 6 showed that there were altogether nine individual items of strategies varying significantly according to the variable of perceived language ability. The results demonstrated that there was a significantly greater percentage of the good students with perceived language ability $(81.2 \%)$ than that of the fair students (75.8\%) and that of the poor students $(62.8 \%)$. On the contrary, the results showed that there was a significantly greater percentage of the poor students with perceived language ability $(53.9 \%)$ than that of the fair students (49.8\%) and that of the good students (32.3\%), for example, help-seeking strategies like 'Asking the interlocutor to simplify the language (UIM 3)' was used by the poor perceived language ability students because of their low level of English language ability.

Also in Table 6, as what was suggested by Green and Oxford (1995), the pattern of variation was classified into three kinds: positive (high $>$ moderate $>$ low), negative (low $>$ moderate $>$ high), and mixed (e.g. moderate $>$ low $>$ high). In the positive pattern (high $>$ moderate $>$ low), the students with higher proficiency level used more strategies than the moderate level students, and the moderate level students used more than the lower level students. On the contrary, in the negative pattern (low $>$ moderate $>$ high), the students with lower proficiency level used more strategies than the moderate level students, and the moderate level students used more than the higher level students. In the mixed pattern (moderate $>$ low $>$ high), the students with moderate proficiency level 
used more strategies than the lower level students, and lower level students used more than the higher level students. For instance, 'Using familiar words, phrases or sentences (CCP 2)' was positive (high $>$ moderate $>$ low; 'Asking the interlocutor to simplify the language UIM 3' showed a negative pattern of variation (low $>$ moderate $>$ high) and 'Thinking in Chinese before speaking CCP12' was a mixed pattern of moderate $>$ low $>$ high.

To conclude, the findings revealed that significant differences were found in the UIM and CCI categories according to the students' perceived language ability as well as in some individual items of CSs in relation to both gender and perceived language ability. However, no significant difference was found in the students' overall reported strategy use and in the strategy category according to gender.

\section{Discussion}

The present study was intended to explore the use of communicative strategies in relation to gender and perceived language ability among tourism-oriented EFL learners in the universities in Southwest China to improve and maintain the oral communication in English. The results mentioned above were discussed as follows:

\subsection{Use of CSs and Students' Gender}

Ellis (1994) claimed that learners' gender is one of the factors which may influence their choices of strategy use to learn a foreign or second language. Based on the previous empirical studies, the gender of the students made a significant difference in language strategy use (e.g. Green and Oxford, 1995; Maubach and Morgan, 2001; Nyikos, 1990; Ok, 2003; Oxford and Nyikos, 1989; Oxford et al., 1993). These studies found the relationship between gender and language learners' choice of strategies, where the frequency and variety of strategy use was significantly greater for females.

Although there was a lack of significant variations of CS employment in overall use and in the CCP, UIM and CCI categories, this study obtained the significant differences of individual CS employment in relation to the student's gender. The findings of this present study demonstrated that the relationship between the gender of students and their strategy use in the two individual items of CCP and the other two individual items of UIM category was very strong. It suggested that females were more interested in interaction, and more cooperative to make themselves understood. This was consistent with the results in Mori and Gobel's study (2006), in which females had more desire to make L2-speaker friends and greater interest in direct contact with English speaking people than their male counterparts. Obviously female students were active in CSs use and showed significantly higher frequency of individual CSs use in CCP, for instance, Using simple expressions CCP 5, particularly in UIM category than their male counterparts, such as Trying to catch the interlocutor's main point UIM 6 . This was reaffirmed by Oxford (1993), claiming that females tended to be more active strategy users than their male counterparts.

Apart from that, one possible explanation for higher frequency of CS use by females was their self-perception, which was consistent with several previous studies in which female students were more positively inclined to language learning than male counterparts (e.g. Bui and Intaraprasert, 2012; Williams et al., 2002; Wright, 1999;). This was probably somewhat strongly influenced by innate characteristics of females. This could be an acceptable reason why females were innately better at language learning (Oxford, Nyikos and Ehrman, 1988) and females had more positive attitudes towards studying foreign languages than their male counterparts.

One more possible explanation for such significant differences was female's sociability. Oxford (1995) pointed out that both brain hemisphericity and socialization differences between male and female have attributed to the differences in strategy use. Two CCP items for coping with communication problems (Using simple expressions CCP 5 and Using familiar words, phrases or sentences CCP 2) and two UIM for understanding interlocutor's messages (Trying to catch the interlocutor's main point UIM 6 and Noticing the interlocutor's gestures and facial expressions UIM10) showed their strong desire for sociability, which was consistent with what Ok (2003, p. 26) mentioned, "females are superior to, or at least very different from, males in many social skills with females showing a greater social orientation".

Finally, the findings of the present study were also supported by the statement of Ghani (2003, p. 33), "males do better than females in the use of some strategies". The results showed that more male than female students reporting the use of certain individual CSs of CCP and CCI categories. These strategies included feeling all right taking risks while speaking (CCI3), making up a new word in order to communicate a desired concept (CCP20) and repeating what the interlocutor has just said (CCP9). The possible explanation for this was that male students had greater willingness to manage anxiety while interacting in English in order to maintain the 
conversation than female students and could be the reason that males were quite self-confident and risk-taking in their oral abilities which were consistent with Maubach and Morgan (2001), males tended to be over-confident in their oral abilities. According to Maubach and Morgan (2001, p. 44), "males seem much more self-reliant in keeping a conversation going, tending to follow their own instincts, sometimes even under-preparing material due to an over-confidence in their oral abilities". They further explained that males, with greater confidence, seem to have a greater enjoyment of speaking activity than female students.

In sum, having a closer look at the results of previous studies and the present study, it might be concluded that language strategy use is a gender-related issue. If females were more active, positive and skillful in using certain strategies to learn a language, then males may need more help in developing such strategies for communication.

\subsection{Use of CCs and Perceived Language Ability}

According to previous studies reviewed by the researcher, language ability influences how students learn foreign or second languages (e.g. Bialystok, 1981; Ok, 2003; Oxford and Nyikos, 1989; Potizer, 1983). For example, Potizer (1983) found that course level affected the strategy choice of foreign language learners, with higher-level students using more communicative or functional strategies. Oxford and Nyikos (1989) also found differences in strategy use as advanced students used functional practice and conversational input elicitation strategies more often than lower level students did. In short, the more advanced the language learner are, the better communication strategy users they will be. So this present study was in line with the previous findings (Barnett, 1989; Oxford, 1993; Sheorey and Mokhtari, 2001).

The present investigation was designed to explore the relationship between the students' perceived language ability and their choices of the CS use. Although the significant differences of CS employment in overall use and in the CCP category were not found, however, the significant differences of CS employment were found in the UIM, CCI categories and individual items of CS employment in relation to student's perceived language ability. The findings of the present study demonstrated that the relationship between student's perceived language ability and their strategy use in the six individual items of CCP, two individual items of UIM category, and one item of CCI were rather strong. A few assumptions could possibly be made to explain why such significant differences existed. The possible assumptions might be: 1) Those students who are perceived as having good language ability are achievement strategy users; 2) Those students who are perceived as having fair language ability are both achievement and reduction strategy users; and 3) Those students who are perceived as having poor language ability are reduction strategy users for employing communication strategies.

The first possible assumption which may be made to explain about higher frequency of strategy use, which was consistent with Oxford (1993), i.e., strategy users with higher language ability are the higher language achievers because of their language ability. The results of a number of studies (Barnett, 1989; Sheorey \& Mokhtari, 2001) revealed that students who perceived as 'good' language level tended to report using a greater range of communication strategies than those who perceived as 'fair' language level and the 'poor' level did. Therefore, the connection between perceived as 'good' language level and the use of more complicated communication strategies, such as 'Using synonym or antonym (CCP 1)' or 'Correcting one's own pronunciation, grammar and lexical mistakes (CCP 3)', might explain the higher frequency of strategy use and are considered to be achievement strategy users. Accordingly, 'Thinking in Chinese before speaking (CCP 12)' and 'Trying to translate into Chinese little by little to understand what the interlocutor has said (UIM 9)' were the L1-based strategy users of perceived as 'fair' language level. Finally, students who perceived as 'poor' language level tended to employ simplification or help-seeking strategies such as 'A sking the interlocutor to simplify the language (UIM 3)'. These kinds of strategies seemed to be less complicated to be used, so the 'poor' level students who were less experienced language learners might not have to put much effort to use them to solve their oral communication problems they encountered. These findings were consistent with what Ellis (1994) stated that the relationship between students' use of strategies and their levels of language proficiency is two-directional; further, MacIntyre (1994, p. 188) stated that "...this might be interpreted to mean that either proficiency influences the choice of strategies or that strategy choice is simply a sign of proficiency level", which revealed that students' employment of a wide range of communication strategies helped them to become successful communication strategy users.

One more possible assumption made for explaining the significant differences has been consistent with what Intaraprasert (2000) suggested that students' motivation might explain the relationship between use of communication strategies and students' levels of language proficiency. As Intaraprasert (2000) mentioned that the higher proficiency students may be highly motivated to seek opportunities to expose themselves to English outside the classroom setting. In this regard, Yule (1996, p. 195) commented that students who experienced 
success in language learning were highly motivated to learn and "motivation may be as much a result of success as a cause." This meant that the effort which high language learning proficiency student put into their language learning may enable them to employ a wider range of strategies, which in turn may help them become high language learning proficiency students.

In short, the findings of the present study showed that the perceived language ability had strong relationship with some individual CSs use, though they had just minor relationship between the overall use of the communication strategies. When taking a closer look at the individual strategies employed by tourism-oriented EFL learners, it showed that the students' language learning levels were rather important because it was easier for the better language learners to become better communication strategy users. Besides, the better language learners were found more likely to be interested in using and highly motivated to use communication strategies when encountering communication problems.

\section{Conclusion}

This present study aimed at investigating the use of communication strategies by tourism-oriented EFL learners to improve and maintain their communication. Communication Strategy Questionnaire was employed to collect data in six universities in the Southwest China. The statistical methods such as ANOVA, Post hoc Scheffe Test and Chi-squire test were adopted for data analysis. The findings of this study showed no significant difference according to three aspects of the investigation related to gender and perceived language ability: the overall CS use, the CS category, and the individual CSs. However, interestingly, the findings showed that there were significant differences in both the CS category and the individual CSs. In terms of gender, the results revealed that females were more interested in interaction and more cooperative to make them understood, while males had greater confidence, were more risk-taking, and more enjoyed doing the speaking activity than female students. Regarding perceived language ability, the students with perceived as 'good' language level tended to use a greater range of communication strategies than those with 'fair' level or 'poor' level did, while the 'fair' level students and the 'poor' level students needed a variety of extra CS training in order to improve and maintain their communication in English. This present study implied that the tourism-oriented EFL learners should be instructed according to their English proficiency level with different access to the use of communication strategies. Moreover, some further research should be conducted in relation to other variables, for example, exposure to oral communication in English, attitudes towards English speaking and English language, etc. to investigate the use of communication strategies.

\section{Acknowledgment}

The authors would like to extend their heartfelt gratitude to all the teachers and the students who were involved in this present study. Special thanks go to Assoc. Prof. Dr. Xueqin Liu in Guangxi University for Nationalities, China; Mr. Yi Wang in Yunnan University, China; and Ms. Xiaofang Jin in Yunnan Normal University, China. Without their help, the completion of this study would be impossible.

\section{References}

Barnett. M. A. (1989). More Than Meets the Eye-foreign Language Reading: Theory and Practice. Prentice Regents.

Bialystok, E. (1981). The Role of Conscious Strategies in Second Language Proficiency. Modern Language Journal, Spring, 65, 24-35.

Bialystok, E. (1983). Some factors in the selection and implementation of communication strategies. In C. Færch, \& G. Kasper (Eds), Strategies in Interlanguage Communication (pp. 100-118). London and New York: Longman.

Bialystok, E. (1990). Communicative strategies. Oxford: Basil Blackwell.

Bui, Q. T. T., \& Intaraprasert, C. (2012). Gender, High School Background and Use of Strategies by English Majors in Vietnam for Coping with Communication Breakdowns. International Journal of Scientific and Research Publications, 2(12), February 2012, 1.

China Daily. (2004). China a top tourist destination by 2020. May 13, 2004. Beijing: China Daily.

Crystal, D. (2003). English as a Global Language. Cambridge: CUP. http://dx.doi.org/10.1017/CBO9780511486999

Dörnyei, Z. (1995). On the Teachability of Communication Strategies. TESOL Quarterly, 29(1), 55-48. http://dx.doi.org/10.2307/3587805 
Dörnyei, Z. (2003). Questionnaire in Second Language Research: Construction, Administration, and Procession. New Jersey: Lawrence Erlbaum Associates.

Dörnyei, Z., \& Scott, M. L. (1997). Review Article, Communication Strategies in a Second Language: $\begin{array}{llll}\text { Definitions and Taxonomies. Language } & \text { Learning, }\end{array}$ http://dx.doi.org/10.1111/0023-8333.51997005

Ellis, R. (1994). The Study of Second Language Acquisition. Hong Kong: Oxford University Press.

Feng, A. (2011). English Language Education Across Greater China. UK: St Nicholas House.

Fraenkel, J. R., \& Wallen, N. E.. (1993). How to Design and Evaluate Research in Education. London: The McGraw-Hill Companies.

Ghani, M. (2003). Language learning strategies employed by L2 learners. Journal of Research (Faculty of Languages \& Islamic Studies), 4, 31-36.

Green, J. M., \& Oxford, R. (1995). A Closer Look at Learning Strategies, L2 Proficiency, and Gender. TESOL Quarterly, 29(2), 261-297. http://dx.doi.org/10.2307/3587625

Intaraprasert, C. (2000). Language learning strategies employed by engineering students learning English at the tertiary level in Thailand. Unpublished Doctoral Dissertation, School of Education, University of Leeds, England.

Jiang, Y. (2003). English as a Chinese language. English Today, 19(2), 3-8.

Larsen-Freeman, D., \& Long, M. (1991). An introduction to second language acquisition research. London: Longman.

Liskin-Gasparro, J. E. (1996). Circumlocution, Communication Strategies, and The ACTFL Proficiency Guidelines: An Analysis of Student Discourse. Foreign Language Annuals, 29(3), 317-330.

MacIntyre, P. D. (1994). Variables underlying willingness to communicate: A causal analysis. Communication Research Reports, 11, 135-142. http://dx.doi.org/10.1080/08824099409359951

Mariani, L. (2010). Communication Strategies: Learning and teaching how to manage oral interaction. NA: Learning Path-Tante Vie Per Imparare.

Maubach, A., \& Morgan, C. (2001). The relationship between gender and learning styles amongst A level modern languages students. Language Learning Journal, 23, 41-47.

Nakatani, Y. (2006). Developing an Oral Communication Strategy Inventory. The Modern Language Journal, 90(ii), 151-168.

Nyikos, M. (1990). Sex-related differences in adult language learning: Socialization and memory factors. The Modern Language Journal, 74(iii), 273-287.

Ok, L. (2003). The relationship of school year, sex and proficiency on the use of learning strategies in learning English of Korean junior high school students. Asian EFL Journal, 5(3), 1-36.

O'Malley, J., \& Chamot, A. (1990). Learning Strategies in Second Language Acquisition. Cambridge: Cambridge University Press. http://dx.doi.org/10.1017/CBO9781139524490

Oxford, R., Nyikos, M., \& Ehrman, M. (1988). Vive la difference? Reflections on sex differences in use of language learning strategies. Foreign Language Annals, 21(4), 321-329. http://dx.doi.org/10.1111/j.1944-9720.1988.tb01076.x

Oxford, R., \& Nyikos, M. (1989). Variables affecting choice of language learning strategies by university students. Modern Language Journal, 73(3), 291-300. http://dx.doi.org/10.1111/j.1540-4781.1989.tb06367.x

Oxford, R. (1993). Research on second language learning strategies. Annual Review of Applied Linguistics, 13, 175-187.

Oxford, R., Park-Oh, Y., Ito, S., \& Sumrall, M. (1993). Japanese by satellite: effects of motivation, language learning styles and strategies, gender, course level, and previous language learning experience on Japanese language achievement. Foreign Language Annals, 26(3), 359-371. http://dx.doi.org/10.1111/j.1944-9720.1993.tb02292.x

Oxford, R. L. (1995). Language Learning Strategies around the World: Cross-Cultural Perspectives. National Foreign Language Center Technical Reports Series, No. 13. University of Hawaii Press.

Paramasivam, S. (2009). Language Transfer as a Communication Strategy and a Language Learning Strategy in 
a Malaysian ESL Classroom. The Asian EFL Journal Quarterly, 11(1), 192-299.

Politzer, R. L., \& McGroarty, M. (1983). An exploratory study of learning behaviors and their relationship to gain in linguistic and communication competence. Manuscript, Stanford University.

Sheorey. R., \& Mokhtari, K. (2001). Differences in the metacognitve awareness of reading strategies among native and non-native speakers. System, 48(1), 431-449. http://dx.doi.org/10.1016/S0346-251X(01)00039-2

Somsai, S., \& Intaraprasert, C. (2011). Strategies for coping with face-to-face oral communication problems employed by Thai university students majoring in English. Journal of Language Studies, 11(3), 83-96.

Tarone, E., Cohen, A., \& Dumas, G. (1976). A closer look at some interlanguage terminology: a framework for communication strategies. Working Papers on Bilingualism, 9, 76-90.

Tarone, E. (1983). Some Thought on the Notion of 'Communication Strategy'. In C. Færch, \& G. Kasper (Eds.), Strategies in Interlanguage Communication (pp. 61-74). London and New York: Longman.

Terrell, T. D. (1977). A natural approach to second language acquisition and learning. The Modern Language Journal, 61(7), 325-337.

Wannarak, A. (2003). Communication Strategies in an EST Context. Research report, Suranaree University of Technology, Nakhon Ratchasima, Thailand.

Williams, M., Burden, R., \& Lanvers, U. (2002). 'French is the language of love and stuff': Student perceptions of issues related to motivation in learning a foreign language. British Educational Research Journal, 28, 503-528. http://dx.doi.org/10.1080/0141192022000005805

Wright, M. (1999). Influences on learners attitudes towards foreign language and culture. Educational Research, 41(2), 197-208. http://dx.doi.org/10.1080/0013188990410207

Yule, G. (1996). Pragmatics. Oxford University Press.

Zhang, Y. (2007). Communication Strategies and Foreign Language Learning. US-China Foreign Language, 5(4), (Serial No. 43).

\section{Appendix}

\section{Communication Strategy Questionnaire (CSQ)}

This survey is intended to collect data about the employment of English communication strategies by Chinese university tourism-oriented EFL learners. This is not a test, so there are no 'right' or 'wrong' answers. Your answers will be used for the research purpose only and will be treated with confidentiality. I appreciate your contribution to answer the questionnaire.

Instructions: There are two main parts of this questionnaire:

Part 1: Your Personal Information

Part 2: Use of Communication Strategies

Part 1

Personal Information

Please provide your personal information by putting a tick $(\checkmark)$ in the box of the choices given or write the response where necessary.

1. Your Gender : $\square$ Male $\quad \square$ Female

2. Your University and major are

3. You would rate your overall English ability based on 100 (full score) as:

$\square$ very good/good (over 80$) \quad \square$ fair (60-79 score) $\quad \square$ poor (under 60 score) 


\section{Part 2}

\section{Communication Strategy Questionnaire}

Instructions: The Communication Strategy Questionnaire is designed to gather information about use of communication strategies in English. In the statements below, you will find various communication strategies. Please read each statement carefully and consider how frequently you employ the given strategies while interacting in English. Then mark your response with a ' $\checkmark$ ' in the corresponding space provided.

"Never" means that while you were interacting in English, you never used the strategy described in the statement.

"Sometimes" means that while you were interacting in English, you used the strategy described in the statement about one fourth the time of the total strategy use.

"Often" means that while you were interacting in English, you used the strategy described in the statement about half the time of the total strategy use.

"Always/almost always" means that while you were interacting in English, you used the strategy described in the statement about more than three quarter the time of the total strategy use.

\section{For example:}

1. When having a conversation in English, have you encountered any difficulties in getting the message across to the interlocutor?

$$
\square \text { Yes } \square \text { No }
$$

If no, proceed to Part Two.

If yes, how often do you deal with the difficulties by doing the following?

\begin{tabular}{|l|l|l|l|l|}
\hline \multirow{2}{*}{ Communication Strategy } & \multicolumn{3}{|l|}{ Frequency of Your Own Communication Strategy Use } \\
\cline { 2 - 5 } & $\begin{array}{l}\text { Always/ } \\
\text { Almost Always }\end{array}$ & Often & Sometimes & Never \\
\hline $\begin{array}{l}\text { 1. Using familiar words, phrases, or } \\
\text { sentences }\end{array}$ & $\checkmark$ & & \\
\hline
\end{tabular}

\section{Part One: Strategies to Cope with Communication Difficulties (CCP)}

1. When having a conversation in English, have you encountered any difficulties in getting the message across to the interlocutor?
$\square \quad$ Yes
No

If no, proceed to Part Two.

If yes, how often do you deal with the difficulties by doing the following?

\begin{tabular}{|l|l|l|l|l|}
\hline \multicolumn{1}{|c|}{ Communication Strategy } & \multicolumn{3}{l|}{ Frequency of Your Own Communication Strategy Use } \\
\cline { 2 - 5 } & $\begin{array}{l}\text { Always/ } \\
\text { Almost Always }\end{array}$ & Often & Sometimes & Never \\
\hline 1. Using synonym or antonym & & & & \\
\hline $\begin{array}{l}\text { 2. Using familiar words, phrases or } \\
\text { sentences }\end{array}$ & & & & \\
\hline $\begin{array}{l}\text { 3. Correcting one's own pronunciation, } \\
\text { grammar and lexical mistakes }\end{array}$ & & & & \\
\hline $\begin{array}{l}\text { 4. Speaking Chinese instead when one } \\
\text { doesn't know how to say in English }\end{array}$ & & & & \\
\hline 5. Using simple expressions & & & & \\
\hline
\end{tabular}




\begin{tabular}{|l|l|l|l|l|}
\hline \multicolumn{1}{|c|}{ Communication Strategy } & Frequency of Your Own Communication Strategy Use \\
\cline { 2 - 5 } & $\begin{array}{l}\text { Always/ } \\
\text { Almost Always }\end{array}$ & & Sometimes & Never \\
\hline $\begin{array}{l}\text { 6. Using nonverbal language such as } \\
\text { body language }\end{array}$ & & & \\
\hline $\begin{array}{l}\text { 7. Spelling or writing out the intended } \\
\text { words, phrases, or sentences }\end{array}$ & & & \\
\hline 8. Referring to objects or materials & & & \\
\hline $\begin{array}{l}\text { 9. Repeating what the interlocutor has } \\
\text { just said }\end{array}$ & & & \\
\hline $\begin{array}{l}\text { 10. Speaking more slowly to gain time } \\
\text { to think }\end{array}$ & & & \\
\hline $\begin{array}{l}\text { 11. Correcting the incorrect and } \\
\text { inappropriate utterances by yourself }\end{array}$ & & & \\
\hline $\begin{array}{l}\text { 12. Thinking in Chinese before } \\
\text { speaking }\end{array}$ & & & \\
\hline $\begin{array}{l}\text { 13. Thinking first of a sentence one } \\
\text { already knows in English and then } \\
\text { trying to change it to fit the situation }\end{array}$ & & & \\
\hline $\begin{array}{l}\text { 14. Asking the interlocutor to confirm } \\
\text { that one's made oneself understood }\end{array}$ & & & \\
\hline $\begin{array}{l}\text { 15. Appealing help from the } \\
\text { interlocutor either verbally or } \\
\text { non-verbally }\end{array}$ & & & \\
\hline $\begin{array}{l}\text { 16. Referring to mobile phone } \\
\text { dictionary or another type of document }\end{array}$ & & & \\
\hline $\begin{array}{l}\text { 17. Drawing a picture fore } \\
\text { 18. Appealing for assistance from } \\
\text { other people around }\end{array}$ & & & \\
\hline $\begin{array}{l}\text { 19. Making use of expressions found } \\
\text { in some sources of media (e.g. movies } \\
\text { or songs) }\end{array}$ & & & \\
\hline $\begin{array}{l}\text { 20. Making up a new word in order to } \\
\text { communicate a desired concept } \\
\text { (Word-coinage) }\end{array}$ & & & \\
\hline 21. Others (Please specify) ........... & & & \\
\hline
\end{tabular}

\section{Part Two: Strategies to Understand the Interlocutor's Message (UIM)}

2. Have you encountered any problems in understanding the interlocutor's message when having communication in English?

$$
\square \text { Yes } \square \text { No }
$$

If no, proceed to Part Three.

If 'Yes', how often do you employ the following strategies to solve the problems?

\begin{tabular}{|l|l|l|l|l|}
\hline \multicolumn{1}{|c|}{ Communication Strategy } & \multicolumn{3}{|l|}{ Frequency of Your Own Communication Strategy Use } \\
\cline { 2 - 5 } & $\begin{array}{l}\text { Always/ } \\
\text { Almost } \\
\text { Always }\end{array}$ & Often & Sometimes & Never \\
\hline 1. Asking the interlocutor to slow down & & & & \\
\hline 2. Asking the interlocutor for a repetition & & & \\
\hline $\begin{array}{l}\text { 3. Asking the interlocutor to simplify the } \\
\text { language }\end{array}$ & & & & \\
\hline
\end{tabular}




\begin{tabular}{|l|l|l|l|l|}
\hline \multicolumn{1}{|c|}{ Communication Strategy } & \multicolumn{2}{|l|}{ Frequency of Your Own Communication Strategy Use } \\
\cline { 2 - 5 } & $\begin{array}{l}\text { Always/ } \\
\text { Almost } \\
\text { Always }\end{array}$ & Often & Sometimes & Never \\
\hline $\begin{array}{l}\text { 4. Asking the interlocutor to write out the key } \\
\text { word }\end{array}$ & & & & \\
\hline 5. Asking the interlocutor to give an example & & & \\
\hline 6. Trying to catch the interlocutor's main point & & & \\
\hline $\begin{array}{l}\text { 7. Appealing for assistance from other people } \\
\text { around }\end{array}$ & & & \\
\hline $\begin{array}{l}\text { 8. Guessing the meaning of what the } \\
\text { interlocutor has said }\end{array}$ & & & \\
\hline $\begin{array}{l}\text { 9. Trying to translate into Chinese little by } \\
\text { little to understand what the } \\
\text { interlocutor has said }\end{array}$ & & & \\
\hline $\begin{array}{l}\text { 10. Noticing the interlocutor's gestures and } \\
\text { facial expressions }\end{array}$ & & & & \\
\hline 11. Others (Please specify) ............ & & & \\
\hline
\end{tabular}

\section{Part Three: Strategies to Carry on the Conversation as Intended (CCI)}

3. Have you encountered any problems in carrying on the conversation as intended when having communication in English?

$\square$ Yes $\square$ No

If no, stop answering the Part Three.

If 'Yes', how often do you employ the following strategies to help you carry on the conversation as intended?

\begin{tabular}{|l|l|l|l|l|}
\hline \multicolumn{1}{|c|}{ Communication Strategy } & \multicolumn{2}{|l|}{ Frequency of Your Own Communication Strategy Use } \\
\cline { 2 - 5 } & $\begin{array}{l}\text { Always/ } \\
\text { Almost } \\
\text { always }\end{array}$ & Often & Sometimes & Never \\
\hline 1. Trying to enjoy the conversation & & & \\
\hline $\begin{array}{l}\text { 2. Sending continuation signals to } \\
\text { show one's understanding }\end{array}$ & & & \\
\hline $\begin{array}{l}\text { 3. Feeling all right for taking risks while } \\
\text { speaking }\end{array}$ & & & \\
\hline $\begin{array}{l}\text { 4. Feeling all right if the conversation does not } \\
\text { go smoothly by keeping talking }\end{array}$ & & & \\
\hline $\begin{array}{l}\text { 5. Responding to the interlocutor despite an } \\
\text { imperfect understanding of the message }\end{array}$ & & & & \\
\hline 6. Others (Please specify) .............. & & & \\
\hline
\end{tabular}

* Contacting the researcher: tzhao65@hotmail.com

Thank you very much for your cooperation!

\section{Copyrights}

Copyright for this article is retained by the author(s), with first publication rights granted to the journal.

This is an open-access article distributed under the terms and conditions of the Creative Commons Attribution license (http://creativecommons.org/licenses/by/3.0/). 